\begin{tabular}{|c|c|c|} 
Postgraduate Bosowa University Publishing (PBUP) & INDONESIAN \\
JOURNAL
\end{tabular}

\title{
PENGARUH NILAI - NILAI KEARIFAN LOKAL TERHADAP GAYA KEPEMIMPINAN TRANSFORMASIONAL PADA PEMERINTAH DAERAH KABUPATEN BONE
}

\author{
The Influence of Locals Wisdom Values on the Transformational Leadership Style in \\ Bone Regional Government \\ Fahril Jaya $^{1}$, Muhlis Ruslan ${ }^{2}$, Haeruddin Saleh ${ }^{2}$ \\ ${ }^{1}$ Magister Manajemen Universitas Bosowa Makassar \\ ${ }^{2}$ Program Studi Manajemen Program Pascasarjana Universitas Bosowa \\ Email: muhammadfahrilmarzuki792@gmail.com
}

Diterima: 12 Agustus 2020 /Disetujui: 05 Desember 2020

\begin{abstract}
ABSTRAK
Penelitian ini bertujuan untuk mengetahui bentuk pengaruh nilai - nilai kearifan lokal pada kepemimpinan transformasional pemerintah daerah kabupaten Bone. Metode pendekatan yang digunakan dalam penelitian ini adalah kualitatif, dimana data diperoleh melalui observasi di lapangan, wawancara mendalam dengan beberapa informan serta melalui analisis dokumen dan studi pustaka. Hasil penelitian menunjukkan bahwa terdapat pengaruh nilai - nilai kearifan lokal terhadap gaya kepemimpinan transformasional pemerintah daerah kabupaten Bone. Hal Ini ditandai dengan semakin besar pemahaman dan aktualisasi nilai - nilai lokal oleh seorang pemimpin pemerintahan, maka akan semakin tinggi gaya kepemimpinan transformasional yang dia terapkan khsuusnya dalam indikator stimulasi intelektual. Kepemimpinan pemerintah daerah harus selalu berbasis pada nilai - nilai kearifan lokal yang diwariskan sebagai wujud identitas aparatur yang berpihak pada masyarakat dan sebagai bentuk refleksi sebuah relevansi atas budaya kerja yang berkembang di Kabupaten Bone.
\end{abstract}

Kata Kunci: Nilai-Nilai Kearifan Lokal, Kepemimpinan Transformasional, Kabupaten Bone

\begin{abstract}
The Purpose of this research is to determine the influence of local wisdom values on the transformasional leadership of the Government of Bone Regency. The approach uses qualitative research. The data is obtained through direct observation in the field, deep interviews with informants and document analysis. The research results are presented descriptively. The results show that the values of local wisdom influence the transformasional leadership style of the Government of Bone Regency. This is indicated by the greater understanding and actualization of local values by the government leader, the higher the transformational leadership style that he applies specifically in indicators of intellectual stimulation. Local government leadership must always be based on the values of wisdom which is inherited as an expression of the identity of the authorities in favor of the community and as a form of reflection of the relevance of the work culture that has developed in Bone Regency.
\end{abstract}

Keywords: The Vlues of Local Wisdom, Transformasional Leadership, The Government of Bone

\section{PENDAHULUAN}

Perkembangan teknologi cukup pesat dan cepat kian berdampak pada perubahan secara drastis segala aspek kehidupan manusia, tak terkecuali pada kehidupan sosial budaya masyarakat. Ironisnya, dengan perkembangan dan proses modernisasi yang terjadi, manusia menyerap nilai - nilai dari luar bahkan terkadang tanpa melakukan proses filterisasi. Sehingga perlahan mulai meminggirkan nilai - nilai lokal sendiri yang menjadi warisan secara turun temurun, dan seharusnya dijaga kebasahaannya. Padahal, kearifan lokal pada dasarnya merupakan sebuah jati diri dari suatu daerah, sesuatu yang membedakan antara daerah yang satu dengan daerah yang lain. Meskipun dalam beberapa wilayah, kerap memiliki jenis kearifan yang sama, dan yang membedakan adalah cara penyebutan dan pemaknaannya. Tetapi secara harfiah dari segi bahasa dan makna dalam bahasa Indonesia seringkali 
identik. Latar belakang bahasa dan budaya di atas berkorelasi juga dengan perbedaan karakteristik kepribadian individu (Florentina \& Alim, 2020). Salah satu daerah yang memiliki nilai kearifan tersebut adalah kerajaan Bone atau lebih tepatnya sekarang Kabupaten Bone.

Bone adalah salah satu daerah yang terletak diujung Timur Sulawesi Selatan. Kerajaan Bone identik dengan kearifan lokal yang terjaga, Selain terkenal dengan hasil alamnya (pertanian, perkebunan, perikanan, dll), juga memiliki torehan sejarah yang cukup menarik (Rizal, 2019; Rusadi, 2019). Kabupaten Bone dengan slogan Bone Makkiade' nya atau Bone beradat, adalah satu dari contoh kasus tersebut. Realitasnya, menunjukkan bahwa nilai - nilai kearifan lokal yang terpelihara melalui proses yang panjang kian mengalami reduksi dalam proses pemaknaan dan maupun proses aktualisasinya. Meskipun jika ditelaah dan dicari dengan seksama masih ada yang tetap memahami dan mengaktualisasikan nilai - nilai kearifan tersebut (Rahmatunnair, 2011; Fahri, 2013).

Proses Aktualisasi nilai - nilai kearifan lokal yang kian hari kian mengalami reduksi seharusnya mampu di counter jika ada tindakan reaktif dari Pemerintah, khususnya para pemimpin pemerintahan. Dalam proses kepemimpinannya, pemimpin pemerintahan seharusnya tampil sebagai frontliner dan juga contoh yang wajib diteladani dalam proses pemahaman maupun penerapan nilai - nilai kearifan lokal tersebut. Karena bagaimanapun perkembangan zaman yang ada, nilai nilai kearifan lokal ini harus mampu dipahami dan diimplementasikan dalam setiap kegiatan pemerintahan. Utamanya dalam proses kegiatan pengambilan kebijakan, dan pelaksanaan tugas, tindakan pengaplikasian ini kerap memiliki hubungan dan relevansi.

Konsep kearifan lokal seperti macca, warani, lempu, dan getteng adalah beberapa contoh nilai kearifan lokal di Kabupaten Bone yang memiliki hubungan yang relevan dengan perkembangan zaman. Nilai ini merupakan hasil pemikiran dari penasehat keajaan Bone yakni Kajaolalliddong yang menjabat pada masa pemerintahan Raja Bone ke - V yakni Latenrirawe Bongkang E. nilai nilai yang dirumuskan Kajaolalliddong mampu bertahan sesuai dengan perkembangan zaman karena memiliki unsur elastisitas. Dalam setiap pengungkapannya, Kajaolalliddong selalu menegaskan dengan cara menganalogikan bahwasanya setiap pemimpin sangat penting untuk memiliki dan menerapkan nilai - nilai tersebut.

Strukutur birokrasi serta mekanisme dalam menjalankan wewenang menjadi bukti bahwa demokrasi dan kepemimpinan bukan hal baru lagi bagi masyarakat Bone. Pengambilan kebijakan kerajaan bukan sepenuhnya menjadi otoritas raja melainkan melibatkan masyarakat melalui perwakilannya dalam ade' pitu. Inilah indikasi bahwa jauh sebelum Konsep modern itu hadir atau dibukukan dalam sebuah teori, pemimpin atau raja - raja zaman dahulu telah menerapkan konsep kepemimpinan transformasional secara praktis dalam proses dan mekanisme kepemimpinannya. Perangkat adat yang ada sebenarnya lebih mirip denganstruktur birokrasi yang ada di negara modern saat ini (Goeliling, at.al, 2020).

Perubahan yang cepat di luar Bone, juga berdampak signifikan terhadap Bone. Kerajaan Bone (sekalipun masih ada) kini tinggal nama saja. Jika mencoba bertanya kepada anak-anak sekolah tentang siapa Raja Bone saat ini maka sebagian besar atau malah semuanya akan menjawab tidak tahu. Berbeda dengan daerah lain di Indonesia yang merupakan daerah bekas kerajaan, seperti kesultanan Jogja yang masih memegang teguh nilai-nilai budaya dan tidak melupakan sejarahnya. Generasi di Bone sebagian besar justru melupakan sejarahnya (Badewi, 2015). Kecintaan daerah lain terhadap budayanya tercermin dari keingintahuan mereka atas sejarah, ini dapat diwujudkan dengan menggelar pagelaran budaya. Di Jogja, tiap tahun diadakan festival keraton sebagai bentuk kecintaan mereka akan budaya lokal. Hal Ini seharusnya menjadi tamparan yang keras bagi masyarakat Bone. Di saat orang asing saja ingin mempelajari budaya Kerajaan kita, sementara masyarakat asli justru melupakan dan meninggalkannya. Lihatlah Cristian Pelras yang menghabiskan waktunya berpuluh puluh tahun demi hanya untk mempelajari kebudayaan Bugis kita (Iqabe, 2017; Faizal, 2015)

Kepemimpinan menjadi fungsi utama dalam memimpin pengikut dengan memainkan peran penting dan strategis dalam kelangsungan hidup suatu organisasi, instansi atau lembaga. Kepemimpinan yang berjalan dengan baik akan memberikan semangat optimis di dalam organisasi (Alim \& Rakhmat, 2020). Pemimpin membuat tujuan, merencanakan, dan mengorganisasikan serta meggerakkan dan mengendalikan seluruh sumber daya yang dimiliki sehingga tujuan perusahaan dapat tergapai secara efektif dan efisien karena adanya kerja tim yang baik. Oleh karena itu, pemimpin suatu organsiasi dituntut untuk selalu mampu menciptakan kondisi yang memuaskaan para pengikutnya dalam bekerja sehingga diperoleh tingkat pengikut yang tidak hanya mampu bekerja akan tetapi juga bersedia bekerja ke arah pencapaian tujuan oganisasi yang akan datang.

Hal tersebut hanya mampu terjadi jika pemimpin dan bawahan punya hubungan yang bersifat mempengaruhi dan dipengaruhi. Pemimpin harus mampu menunjukkan gaya transformasional dalam menjalankan kepemimpinannya dimana harus mampu memberikan contoh yang baik dan patut untuk ditiru. Karena dengan kepemimpinan tipe transformasional, pemimpin senatiasa berusaha menginspirasi bawahan untuk memberikan kinerja yang luar biasa (Riadi, 2017). Artinya, kepemimpinan transformasional memiliki berbagai cara untuk memotivasi kepada pengikutnya agar dapat meningkatkan kinerja pengikutnya dengan cara memberikan dorongan yang lebih kepada pemngikut, memberikan contoh untuk lebih mementingkan kelompoknya dibanding kepentingan individu untuk kebaikan bersama dan memberikan fasilitas serta kebebasan kepada pengikut dengan tidak melepaskan 
prosese pengawasan untuk lebih semangat dalam bekerja. Kepemimpinan transformasinonal adalah sebuah gaya kepemimpinan dimana keadaan para pengikut dari seorang pemimpin transformasional merasa adanya kepercayaan, kekaguman, kesetiaan, dan hormat terhadap pemimpin tersebut, serta termotivasi untuk melakukan lebih dari pada yang awalnya diharapkan oleh mereka (Yukl, 2011)

Dalam teori kepemimpinan transformasional pada dasarnya terdapat faktor atau indikator yang harus dicapai agar seorang pemimpin tersebut dikatakan memiliki gaya kepemimpinan tipe transformasional. Adapun indikator indikator tersebut (Robbins dan Judge 2008) diantaranya adalah

\section{a. Idealized Influence}

Idealized influence berarti perilaku seorang pemimpin mampu memberikan visi dan misi. Memunculkan rasa bangga, serta mendapatkan respect dan kepercayaan dari bawahan. Bawahan merasa bangga bisa bekerja sama dengan pemimpinnya, dan mempercayai kapasitas pemimpinnya dalam memecahkan masalah.

\section{b. Inspirational Motivation}

Perilaku pemimpin yang mampu mengkomunikasikan harapan yang tinggi, menyampaikan visi bersama secara menarik dengan menggunakan symbol - symbol untuk memfokuskan upaya bawahan dalam mencapai tujuan yang mengahsilkan kemajuan penting bagi organisasi.

\section{c. Intellectual Stimulation}

Perilaku pemimpin yang mampu meningkatkan kecerdasan bawahan untuk meningkatkan kreativitas dna inovasi mereka, meningkatkan rasionalitas, dan pemecahan masalah secara cermat.

\section{d. Individualized Consideration}

Prilaku pemimpin yang mampu memberikan perhatian pribadi, memperlakukan masing - masing bawahan secara individual sebagai seorang individu dengan kebutuhan, kemampuan dan aspirasi yang berbeda, serta melatih dna memberikan saran. Ini juga berarti memperlakukan masing - masing bawahan sebagai individu serta mendampingi mereka memonitor dan menumbuhkan peluang.

Dari beberapa pernyataan yang ada dapat disimpulkan bahwa kepemimpinan transformational merupakan suatu cara atau gaya mempengaruhi perilaku orang lain untuk mencapai suatu tujuan berkaitan erat dengan konsep tentang kepemimpinan yang merupakan esensi manajemen pada sebuah organisasi, dimana gaya transformasional lebih menekankan kepada gaya pemimpin yang terbuka serta punya daya pengaruh untuk mempengaruhi bawahan secara kolektif baik melalui kata maupun tindakannya (Martha, 2013; Aprilya, 2020).

Sedangkan nilai-nilai kearifan lokal yang dimaksud dalam penelitian ini adalah nilai-nilai utama dalam masyarakat Bugis yang dijadikan pegangan dalam menjalani aktivitas kehidupan. Nilai-nilai tersebut yaitu: (1) Lempu, pada perkataan Bugis, jujur disebut lempu'. Menurut arti logatnya lempu' sama dengan lurus sebagai lawan dari bengkok. Dalam berbagai konteks, adakalanya kata ini juga berarti ikhlas, benar, baik atau adil (Matthes dalam Rahim, 2011); (2) Macca, (Matthes dalam Rahim (2011) cenderung mengartikan acca bukan hanya sekedar pandai atau pintar saja, tetapi juga merujuk kepada cendekia atau intelek; (3) Warani, adalah keberanian atau kemampuan untuk menyampaikan kebenaran tanpa rasa takut. Juga berani mengakui kesalahan yang dia lakukan dan mau menanggung segala konsekuensi akibat kesalahannya. (Matthes dalam Rahim, 2011); (4) Getteng berarti keteguhan. yang dimaksud di sini adalah getteng dalam bahasa Bugis. Selain berarti teguh, kata inipun berarti tetap asas atau setia pada keyakinan, kuat dan tangguh dalam pendirian, erat memegang sesuatu (Machmud dalam Rahim, 201; Supartiningsih, 2010).

\section{METODE PENELITIAN}

Penelitian ini menggunakan metode kualitatif dengan melakukan pendekatan survey. Lokasi pelaksanaan penelitian pada kantor pemerintah Kabupaten Bone tepatnya pada SKPD. Adapun responden yang ada sebanyak 10 orang dan untuk mengambil sampel sebagai responden peneliti menggunakan pendekatan rumus solvin dengan hasil sebanyak 95 responden yang bersumber dari berbagai struktur Jabatan kepemeimpinan dalam peerintahan yang ada didalamnya (Sugiyono,2012). Kaitan dengan pengamatan awal variable yang diteliti diantaranya variable macca (X1), warani (X2), lempu (X3), getteng (X4), dan Kepemimpinan Transformasional (Y).

Instrumen dalam penelitian dengan melakukan wawancara sebagai langkah awal untuk mendapatkan informasi yang ditandaklanjuti dengan melakukan wawancara dan observasi terhadap responden yang terpilih. Adapun untuk metode analisis penulis, dilakukan dimulai dengan pencatatan data dan sumber data, reduksi data, penyajian data, penyimpulan dan verifikasi dan terakhir sampai tahap temuan penelitian.

\section{HASIL DAN PEMBAHASAN}

Struktur jabatan bukanlah merupakan penghalang bagi pegawai untuk melaksanakan pekerjaan sebagai bagian dari tugas dan konsisten. Adapun karekateristik responden berdasarkan struktur jabatan dalam pemerintahan pada table 1 dibawah ini:

Tabel 1. Karakteristik Responden Menurut Jabatan

\begin{tabular}{llcc}
\hline No & Uraian & Frekuensi (orang) & Prosentase (\%) \\
\hline 1 & Bupati & 1 & 10 \\
2 & Kepala Dinas & 1 & 10 \\
3 & Camat & 4 & 40 \\
4 & Lurah & 4 & 40 \\
\hline & Total & 10 & 100 \\
\hline
\end{tabular}

Sumber: Data Primer Diolah, 2020

Tabel 1, Menjelaskan bahwa komposisi responden menurut Struktur jabatan untuk Bupati berjumlah 1 orang $(10, \%)$ untuk Kepala Dinas sebanyak 1 Orang (10\%), 
untuk Camat sebanyak 4 Orang atau $40 \%$ dan untuk Lurah sebanyak 4 orang atau $(40 \%)$.

a. Tingkat Pemahaman dan Aktualisasi Nilai Kearifan Lokal

Berdasarkan data yang diperoleh sebelumnya, hanya ada 3 pemimpin instansi pemerintahan di Kabupaten Bone yang paham dan mengaktualisasikan nilai - nilai kearifan lokal tersebut. Pemahaman dan aktualisasi Ketiga informan tersebut dapat digambarkan dalam tabel 2 sebagai berikut:

Tabel 2. Tingkat Pemahaman dan aktualisasi Nilai Kearifan Lokal

\begin{tabular}{c|c|c}
\hline Informan & Pemahaman & Aktualisasi \\
\hline Lurah Pallette & $\begin{array}{c}\text { Paham secara } \\
\text { historikal }\end{array}$ & $\begin{array}{c}\text { Diaktualisasikan sesuai } \\
\text { dengan makna dan sampai } \\
\text { pada tahap ekstrapolasi }\end{array}$ \\
$\begin{array}{c}\text { Kepala Dinas } \\
\text { Kebudayaan }\end{array}$ & $\begin{array}{c}\text { Paham secara } \\
\text { historikal }\end{array}$ & $\begin{array}{c}\text { Diaktualisasikan sesuai } \\
\text { dengan makna dan sampai } \\
\text { pada tahap ekstrapolasi }\end{array}$ \\
Bupati Bone & Paham secara & Diaktualisasikan sesuai \\
& Historikal & $\begin{array}{c}\text { dengan makna dan sampai } \\
\text { pada tahap ekstrapolasi }\end{array}$ \\
\hline
\end{tabular}

Sumber: Data Primer Diolah, 2020

Tabel 2, Tingkat pemahaman Informan dan aktualisasi nila - nilai kearifan local pada dasarnya dapat dideskripsikan dengan hasil bahwa ketiga pemimpin pemerintahan di Kabupaten Bone (Lurah Pallette, Kepala Dinas Kebudayaan, dan Bupati Bone) pada dasarnya paham nilai - nilai kearifan local (macca, warani, lempu, getting) sesuai dengan makna historikalnya dan untuk tahap aktualisasinya diaktualisasikan sesuai dengan makna historical dan kian mengalami ekstrapolasi (pengembangan makna).

b. Tingkat Pemahaman Terhadap Gaya Kepemimpinan

Transformasioal

Tingkat pemahaman pemimpin pemerintahan di Kabupaten Bone terhadap gaya kepemimpinan transformasional dapat digambarkan dalam table 3 sebagai berikut:

Tabel 3. Pemahaman Pemimpin terhadap Gaya Kepemimpinan Transformasional

\begin{tabular}{lll}
\hline $\begin{array}{c}\text { No } \\
\text { Informan }\end{array}$ & $\begin{array}{c}\text { Tingkat } \\
\text { Pemahaman }\end{array}$ & \multicolumn{1}{c}{$\begin{array}{c}\text { Indikator } \\
\text { Kepemimpinan } \\
\text { Transformasional }\end{array}$} \\
\hline Lurah Pallette & $\begin{array}{l}\text { Tingkat } \\
\text { Pemahaman } \\
\text { Ekstrapolasi }\end{array}$ & $\begin{array}{l}\bullet \text { Kharismatik } \\
\bullet \text { Motivasi Inspirasi }\end{array}$ \\
\hline Kepala Dinas & Tingkat & $\bullet$ kharismatik \\
Kebudayaan & Pemahaman & $\bullet$ Pengaruh Ideal \\
& Ekstrapolasi & $\bullet$ motivasi Inspirasi \\
\hline Bupati Bone & Tingkat & $\bullet$ Pengaruh Ideal \\
& Pemahaman & $\bullet$ Kharismatik \\
& ekstrapolasi & $\bullet$ Motivasi Inspirasi \\
& & $\bullet$ Stimulasi Intelektual \\
& & $\bullet$ Konsederasi Individu \\
\hline
\end{tabular}

Pada Tabel 3, menjelaskan tingkat pemahaman pemimpin pemerintahan (Lurah Pallette, Kepala Dinas
Kebudayaan Kabupaten Bone dan Bupati Bonr) terhadap gaya kepemimpinan transformasional dengan deskripsi, Lurah Pallette Paham pada tingkat ekstrapolasi dan memenuhi indicator kharismatik dab motivasi inspirasi. Kepala dinas Kebudayaan Kabupaten Bone paham pada tingkat ekstrapolasi dan memenuhi indicator kharismatik, pengaruh ideal dan motivasi inspirasi. Dan Buoati Bone paham pada tingkat ekstrapolasi dan memenuhi indicator Pengaruh ideal, kharismatik, motivasi inspirasi, stimulasi intelektual dan konsederasi individu.

\section{Nilai Kearifan Lokal}

\section{a. Macca}

Secara sederhana, macca berarti pintar atau cerdas. Jika dikaitkan dengan personality, maka macca bisa berarti intelek. Adapun macca menurut Konsep Lamellong (Andi Palloge Petta Naba: Sejarah Kebudayaan Bone). Adapun yang dimaksud dengan Macca menurut pemikiran Kajaolalliddong yakni:

1. Macca Pinru Ada (Pintar dalam memilih kata - kata yang tepat dalam percakapan)

2. Macca Duppai ada (Pintar memahami atau memaknai maksud yang disampaikan oleh lawan bicara)

3. Pintar dalam memberikan perintah

4. Penyesuaian antara kata - kata dan perbuatan

b. Warani

Adapun yang dimaksud dengan Lempu (jujur) menurut pemikiran Kajaolalliddong sebagai tolak ukur daripada nilai Lempu (jujur) tersebut, yaitu:

1. Orang yang bersalah padanya dimaafkan

2. Dia dipercaya dan tidak mengkhianati kepercayaan itu

3. Tidak serakah atau tidak menginginkan yang bukan haknya

4. Tidak dituntutnya suatu kebaikan, kalau hanya dia yang menikmatinya, hanya untuk kepentingan pribadinya.

c. Lетрu

Terkait dengan nilai lempu, tergambar dalam sebuah pappaseng yang memberikan nasehat untuk selalu berlaku jujur, yang dikutip dari percakapan antara Kajaolalliddong dengan arumpone. Yang dimaksud dengan Warani menurut pemikiran Kajaolalliddong adalah

1. Berani mengakui kesalahan

2. Berani mempertahankan sesuatu yang benar meskipun dicerca

3. Konsisten terhadap konstitusi (pangngadereng) baik terhadap siapapun dalam pelaksanaan tupoksi masing - masing.

d. Getteng

Yang dimaksud dengan getteng (teguh) meupakan suatu perilaku yang memegang teguh prinsipprinsip yang telah dibuatnya dan berlandaskan pada nilainilai kebenaran (tongeng). Seseorang itu memiliki sifat getteng (teguh), jika:

1. Tidak mengingkari janji dan tidak melangkahi (mengkhianati) perjanjian 
2. Tidak mengurai barang jadi

3. Tidak mengubah keputusan

4. Ketika mengadili, terbitnya keputusan adalah tanda berhenti.

Untuk Aktualisas Nilai Kearifan lokal pemimpin pemrintahan Kabupaten Bone sesuai dengan tupoksi masing - masing, dapat dilihat pada tabel 5 berikut:

Tabel 4. Frekuensi Aktualisasi Nilai Kearifan Lokal

\begin{tabular}{lccccc}
\hline \multicolumn{1}{c}{ Informan } & \multicolumn{4}{c}{ Frekuensi Aktualisasi Nilai } \\
& Macca & \multicolumn{1}{c}{ Kearifan Lokal } & Mean \\
& 6 & 3 & 2 & 4 & 2.5 \\
\hline $\begin{array}{l}\text { Lurah Pallette } \\
\text { Kepala Dinas }\end{array}$ & 5 & 4 & 4 & 3 & 3 \\
$\begin{array}{l}\text { Kebudayaan } \\
\begin{array}{l}\text { Kabupaten Bone } \\
\text { Bupati Bone }\end{array}\end{array}$ & 5 & 2 & 5 & 4 & 2.66 \\
\hline Jumlah & 16 & 9 & 11 & 11 & 8.11 \\
\hline Sumber: Data Primer Diolah, 2020 & & &
\end{tabular}

Tabel 4, tentang frekuensi aktualisasi nilai kearifan lokal menunjukkan jumlah aktualisasi nilai kearifan lokal oleh pemimpin pemerintahan kabupaten Bone (Lurah Pallette, Kepala Dinas Kebudayaan, Dan Bupati Bone) dengan hasil dimana Lurah Pallette mengaktualisasikan 6 nilai macca, 3 nilai Warani 2 nilai lempu dan 4 nilai getteng dengan total 15 nilai dari 6 jumlah tupoksi. Kepala Dinas kebudayaan 5 nilai macca, 4 nilai warani, 4 nilai lempu dan 3 nilai getteng dengan total 16 nilai dengan jumlah 5 tupoksi. Sedangkan untuk Bupati Bone 5 nilai macca, 2 nilai warani, 5 nilai lempu dan 4 nilai getteng dengan total 16 nilai dari 6 tupoksi.

Kepemimpinan transformasionl pada dasarnya memiliki beberapa indikator, yakni; (1) Kharismatik, (2) Pengaruh Ideal, (3) Stimulasi Intelektual, (4) Motivasi Inspirasi; dan (5) Konsederasi Individu. Untuk mengetahui lebih jelas tentang pencapaian dari setiap indikator tersebut, dapat dilihat pada table 5 tentang frekuensi pencapaian indikator kepemimpinan transformasional pemerintah kabupaten Bone dalam pelaksanaan tugas pokok dan fungsi :

Tabel 5. Frekuensi Pencapaian Indikator Kepemimpinan

Transformasional pada Pemerintah Daerah Kabupaten Bone Dalam Proses Pelaksanaan Tugas Pokok dan Fungsi

\begin{tabular}{lcccccc}
\hline \multirow{2}{*}{ Informan } & \multicolumn{5}{c}{ Indikator } & Mean \\
\cline { 2 - 6 } & Kharismatik & $\begin{array}{c}\text { Pengaruh } \\
\text { Ideal }\end{array}$ & $\begin{array}{c}\text { Stimulasi } \\
\text { Intelektual }\end{array}$ & $\begin{array}{c}\text { Motivasi } \\
\text { Inspirasi }\end{array}$ & $\begin{array}{c}\text { Konsederasi } \\
\text { Individu }\end{array}$ & \\
\hline Lurah Pallette & 1 & 4 & 2 & 0 & 3 & 1.66 \\
\hline $\begin{array}{l}\text { Kepala } \\
\begin{array}{l}\text { Dinas } \\
\text { Kebudayaan }\end{array}\end{array}$ & 2 & 3 & 1 & 0 & 1 & 1.4 \\
\hline $\begin{array}{l}\text { Bupati } \\
\text { Bone }\end{array}$ & 3 & 6 & 1 & 1 & 4 & 2.5 \\
\hline \multicolumn{1}{c}{ Junmlah } & 6 & 13 & 4 & 1 & 8 & 5.56 \\
\hline
\end{tabular}

Sumber: Data Primer Diolah, 2020

Tabel 5 di atas, menunjukkan jumlah pencapaian indikator kepemimpinan transformasional oleh pemimpin pemerintahan Kabupaten bone (Lurah Pallette, Kepala Dinas Kebudayaan, dan Bupati Bone) dalam pelaksanaan tupoksi dengan hasil dimana Lurah Pallette untuk Indikator kharismatik berjumlah 1, indikator Pengaruh ideal 4, Stimulasi Intelektual 2, Motivasi Inspirasi ), dan
Konsederasi Individu 3. Kepala Dinas Kebudayaan dengan rincian indikator Kharismatik 2, Pengaruh Ideal 3 Stimulasi Intelektual 1, Motivasi Inspirasi 0 dan Konsederasi Individu 1. Sedangkan untuk Bupati Bone mencapai indikator kharismatik sebanyak 3 kali, Pengaruh ideal 6, Stimulasi Inteletual 1, Motivasi Inspirasi 1 dan Konsederasi Individu 4. Kesimpulan yang ditemukan bahwa kharismtaik, Pengaruh Ideal dan Konsederasi Indikator yang lebih mudah dicapai oleh pemimpin pemerintahan dalam pelaksanaan tupoksinya.

Pada penelitian ini dapat ditemukan bahwa nilai kearifan lokal Macca dan Warani pada dasarnya memiliki pengaruh terhadap aktualisasi kepemimpinan transformasional (dalam pelaksanaan Pemerintahan di Kabupaten Bone) Khususnya terhadap indikator intellectual stimulation dan Idealized Influence. Artinya, semakin tinggi aktualisasi nilai macca dan Warani yang diterapkan, maka semakin tinggi juga indikator stimulasi Intelektual yang tercapai. Sedangkan Nilai Lempu dan Getteng pada dasarnya memiliki pengaruh terhadap kepemimpinan transformasional di Pemerintahan Kabupaten Bone Khususnya terhadap indikator Pengaruh Ideal. Artinya, semakin tinggi aktualisasi nilai Lempu dan Getteng yang diterapkan, maka semakin tinggi juga indikator Pengaruh Ideal yang tercapai.

Dalam Proses pemahaman dan aktualisasi nilai nilai kearifan local dalam pemerintah daerah kabupaten Bone pada dasarnya didukung oRelevansi nilai kearifan lokal tersebut dengan ajaran syariat islam sebagaimana yang kita ketahui bersama dimana semua informan yang penulis wawancarai adalah beragama islam (muslim). Kedua, Kesesuaian antara nilai - nilai kearifan lokal (macca, warani, lempu, getteng) dengan budaya kerja yang berkembang di Kbaupaten Bone. Dimana pemerintahan daerah kanupaten Bone menekankan pada budaya kerja yakni, kerja keras, kerja cerdas, kerja ikhlas dan kerja tuntas. ketiga, Nilai kearifan lokal tersebut adalah sebuah produk dan warisan secara turun temurun dari para leluhur kabupaten Bone yang senantiasa masih terjaga eksistensinya, meski dalam proses aktualisasinya kian mengalami reduksi makna historis hingga kurangnya pemahaman yang bisa sampai pada tahap ekstrapolasi Keempat, Nilai - nilai kearifan lokal tersebut senantiasa mengajarkan sebuah kebaikan sehingga eksistensinya kian diyakini masyarakat sebagai sebuah nilai positif.

Berpandangan dari hal tersebut maka dapat diprediksi jika nilai nilai kearifan lokal ini diaktualisasikan dalam pemerintahan khsusunya oleh pemimpin pemerintahan maka setidaknya akan tercapai manfaat - manfaat diantaranya sebagai berikut penyelenggaraan pemerintahan akan dipercaya karena pemimpinnya berpegang teguh pada kearifan yang telah dipercaya secara turun temurun dapat Meningkatkan citra dan nilai pemerintah di mata masyarakat, bentuk pelayanan akan lebih merata karena didorong oleh nilai nilai kearifan lokal yang warani dan lempu, dan kondisi pemerintahan akan lebih stabil dan terciptanya saling menghargai antara pemerintah dan rakyat maupun antara pemimpin pemerintahan dengan bawahan dan instansi 
lain.Selain faktor pendukung tersebut, ada juga beberapa faktor yang menghambat aktualisasi nilai - nilai kearifan lokal tersebut dalam pemerintahan daerah kabupaten Bone seperti, Kurangnya kesadaran masyarakat pada umumnya dan pemimpin pemerintahan pada khsusunya untuk memahami nilai kearifan lokal tersebut secara komprehensif baik secara makna harfiah atau historis maupun secara ekstrapolasi, kurangnya sosialisasi dari pemerintah khsuusnya instansi yang berkaitan dengan kebudayaan tentang makna penting dari nilai - nilai kearifan lokal tersebut serta Berkembangnya budaya modern melalui akulturasi dan asimilasi sehingga lambat laun perlahan disadari datau tidak kian mengikis eksistensi kearifan lokal kita.

\section{KESIMPULAN DAN SARAN}

Hasil penelitian dan pembahasan dapat disimpulkan bahwa terdapat pengauh parsial antara Nilai Kearifan Lokal Macca dan Warani dengan Kepemimpinan transformasional (khususnya stimulasi Intelektual) pada pemerintahan daerah Kabupaten Bone. Artinya semakin paham dan besar aktualisasi nilai macca dan warani kedalam pelaksanaan pemerintahan, maka akan semakin besar gaya kepemimpinan transformasional (Stimulasi Intelektual) yang dipraktekkan pemimpin tersebut. Ada pengaruh parsial antara Nilai Kearifan Lokal lempu dan Getteng dengan Kepemimpinan transformasional (khususnya pada indicator Pengaruh Ideal) pada pemerintahan daerah Kabupaten Bone. Artinya semakin paham dan besar aktualisasi nilai lempu dan Getteng ke dalam pelaksanaan pemerintahan, maka akan semakin tinggi gaya kepemimpinan transformasional (Pengaruh Ideal) yang dicapai pemimpin tersebut.

Berdasarkan kesimpulan di atas maka saran yang diberikan yaitu untuk membangun dan mendukung kegiatan - kegiatan pendidikan berbasis dan bernuansa budaya lokal, baik berupa lembaga formal, informal maupun nonformal agar nilai kearifan lokal dapat terjaga dan diwariskan demi terciptanya pemimpin yang transformasional dimasa mendatang.

\section{DAFTAR PUSTAKA}

Alim, S., \& Rakhmat, H. A. B. (2020). The Construction of Academic Optimism Scale (AOS) to Describe Optimism in Educational Setting. Ecosystem, 20, 199-206.

Aprilya, Nugrahani R. Dkk. Hubungan Antara Gaya Kepemimpinan Transformasional dengan Komitmen Organisasi pada Karyawan The Sunan Hotel Solo. Program Studi Psikologi Fakultas Kedokteran Universitas Sebelas Maret. Diakss Tanggal 21 Januari 2020.

Andhy Perdana, Martha. 2013. Pengaruh Gaya Kepemimpinann Transformasional dan Transaksional terhadap kinerja karyawan : Studi Kasus pada Karyawan Tetap PT Mustika Bahana Jaya. Lumajang. Universitas Brawiajya
Badewi, Hadis M. Relasi Antar Manusia Dalam Nilai nilai Budaya Bugis : Perspektif Filsafat dialogis Martin Buber. STIE Muhammadiyah, Palopo, Sulawesi Selatan Jurnal Filsafat, Vol. 25, No. 1, Februari 2015

Faisal. 2015. Nilai - Nilai Kepemimpinan Tradisional dlam Komunitas Adat Kajang di Sulawesi Selatan. Balai Pelestarian Nilai Budaya Makassar. Makassar. Diakses Tanggal 22 Februari 2020.

Faris Budiman Annas. 2013. Analisis Eksistensi Kearifan Lokal Huyula Desa Bongoime Provinsi Gorontalo. Skripsi. Fakultas Ekologi Manusia. Institusi Pertanian Bogor

Florentina, T., \& Alim, S. (2020). Factors Analysis of IPIP-BFM-50 as Big Five Personality Measurement in Bugis-Makassar Culture. Ecosystem, 20, 156-167

Gary, Yukl. 2010. Leadership In Organization Edisi $6^{\text {th }}$. Upper Saddle River. New Jersey

Iqabe, Sadidul. Kepemimpinan Berbasis Budaya Lokal Dalam Menciptakan Iklim Sekolah. Universitas Pendidikan Indonesia.Jurnal Administrasi Pendidikan Vol.XXIV No.2 Oktober 2017.

Mahmud, Irfan M. The archeology of Sulawesi, terra australis 48. 2016

Rahim, A Rahman. Nilai - nilai Utama Kebudayaan Bugis. Ombak. Yogyakarta. 2011

Rahmatunnair. 2011. Kontekstualisasi Pangadereng dalam Penegakan Syariat Islam pada Masyarakat Bugis Bone. Dosen Jurusan Syariah STAIN WATAMPONE. Watampone. Diakses Tanggal 23 Januari 2020

Rezki Fahri R. 2013. Aktualisasi Nilai Budaya Lokal dalam Kepemimpinan Pemerintahan Kota Palopo.

Riadi, Muchlisin. 2017. Kajian Pustaka.com. Kepemimpinan Transformasional. Diakses tanggal 25 Desember 2019

Rizal, Guru. 2019. Contoh Kearifan Lokal. Contohsoal.co.id. 10 September2019

Robbins, Stephen P. \& Timothy A. Judge. 2008. Perilaku Organisasi edisi Ke-12. Salmeba Empat. Jakarta

Rusadi, Muchlisin, 2019, Pengertian Fungsi Dan Dimensi Kearifan Lokal. kajianpustaka.com, 12 September 2019

Sashkin, Marshall dan Sashkin, Molly. 2011. Prinsip Prinsip Kepemimpinan. Jakarta. Erlangga/

Siagian, Sondang P. 2010. Teori dan Praktek Kepemimpinan. Jakarta. Rinneka Cipta.

Si Manis. 2017. Pengertian Kearifan Lokal, ciri, bentuk, Ruang Lingkup, dan Contoh Kearifan Lokal menurut Para ahli. Pelajaran.co.id. 12 September 2019

Supartiningsih. Konsep Ajjoareng-Joa' Dalam Tatanan Sosial Masyarakat Bugis (Perspektif Filsafat Sosial) Staf Pengajar Fakultas Filsafat UGM Yogyakarta. Jurnal Filsafat Vol. 20, Nomor 3, Desember 2010

Goeliling, A., Marjuni, S., \& Said, M. (2021). Kepemimpinan Tranformasional: Determinan Faktor Kinerja Karyawan Hotel Harper Perintis By Aston 
Di Kota Makassar. Indonesian Journal of Business and Management, 2(2), 56-62.

https://doi.org/10.35965/jbm.v2i2.426 